\title{
Carbon and ecological footprints: tools for measuring the sustainability of the Institute of Engineering at the UABC, Mexicali, BC, Mexico
}

\author{
M. Quintero-Núñez ${ }^{1}$, M. C. López-Millán ${ }^{1}$, F. Bisegna ${ }^{2}$, \\ O. R. Garcia-Cueto ${ }^{1}$, S. Ojeda-Benitez ${ }^{1} \&$ N. Santillán-Soto ${ }^{1}$ \\ ${ }^{1}$ Instituto de Ingeniería. \\ Universidad Autónoma de Baja California, México \\ ${ }^{2}$ Astronautic, Electrical and Energy Engineering Department, \\ University of Rome Sapienza, Italy
}

\begin{abstract}
This paper intends to recognize carbon and ecological footprints as tools to measure the sustainability of the Institute of Engineering ( $\mathrm{IoE}$ ) of the Autonomous University of Baja California (UABC), in Mexicali, BC, Mexico in 2013. The ecological footprint (EF) is defined herein as the ecologically productive territory that is needed for the absorption of residuals and the generation of resources deemed necessary for the subsistence of a defined population. The carbon and ecological footprints are based on the fact that the EF requires the value of the carbon footprint prior to carrying out the conversion to global hectares (hag). The methodology that was utilized herein is based on the quantification of tons of $\mathrm{CO}_{2}$ derived from the following factors: water, energy and paper consumption, commuting by the members of the IoE, and lastly, construction of the building. The results are provided in tons of $\mathrm{CO}_{2}$ and hectares of absorption land deemed necessary for emissions of $\mathrm{CO}_{2}$ onto the atmosphere, which are the result of activities carried out by the IoE. The ecological footprint is $1.00 \mathrm{hag} /$ person of global hectares. Such an outcome is useful for purposes of gaining knowledge on the level of sustainability of the IoE and to compare it with that of other academic institutions.
\end{abstract}

Keywords: carbon footprint, ecological footprint, $\mathrm{CO}_{2}$ absorption, global hectare, sustainability. 


\section{Introduction}

At present, environmental pollution constitutes a global problem, and in some instances it is tackled from such a wide array of standpoints that the common stakeholder is led to conclude that doing something about it is beyond his or her reach. In addition, the environmental impact linked to certain industrial activities, or to overall urban traffic and the immediate setting is deemed as not being considered. That is why the Institute of Engineering (IoE) has undertaken an approach seeking to assess its ecological footprint, which in the end translates as a way of measuring the impact anthropomorphism has brought about on Earth.

Now, in order to gain knowledge on the ecological footprint of a subject, it is necessary to first of all have knowledge about its carbon footprint. It may be said that the surface of an ecologically productive territory deemed necessary to generate the resources that are utilized and to assimilate the residuals (residues) produced for a duly defined population with a particular life style constitutes its ecological footprint as described by Wackernagel and Rees [1]; thus, the carbon footprint is the amount of $\mathrm{CO}_{2}$ that is emitted to the atmosphere as a result of performing a certain activity.

Nowadays, the term carbon footprint is an abbreviation that is used to refer to the amount of carbon dioxide emitted by a certain activity or by an organization. The carbon footprint is also an environmental indicator that gives rise to net emissions of greenhouse gases measured as $\mathrm{CO}_{2} \mathrm{e}\left(\mathrm{CO}_{2}\right.$ equivalent). Greenhouse gases $(\mathrm{GHG})$ are expressed in tons of $\mathrm{CO}_{2} \mathrm{e}$ taking as reference their global warming power.

The carbon component of the ecological footprint entails a slightly different approach, which is that of transporting the amount of carbon dioxide to the amount of productive land or the area required to sequester the carbon dioxide emissions. The latter is explained in terms of the demand placed on the Planet resulting from the burning of fossil fuels. Important advantages are gained by measuring the carbon component this way.

Several studies on the ecological footprint of various academic institutions around the world have been conducted. And with regards to this research paper in particular, several methodologies used for purposes of assessing the ecological footprint have been conducted at various universities, and on the basis of the information presented herein, as well as on the limitations regarding the gathering of data, a methodology for obtaining the ecological footprint was thereby developed, which is described as follows.

\section{Methodology}

In order to obtain the ecological foot print of the IoE, which comprises two buildings (Figures 1 and 2), with the first one, a two-floor facility, and the second one a three-floor building, accounting for a total surface of $3099 \mathrm{~m}^{2}$, five factors were taken into account for such purposes: (a) consumption of electrical power, water, recycled paper, construction of the building itself, and commuting of people 
that work or study in the premises. The sum of all these factors will result in the ecological footprint of the IoE.

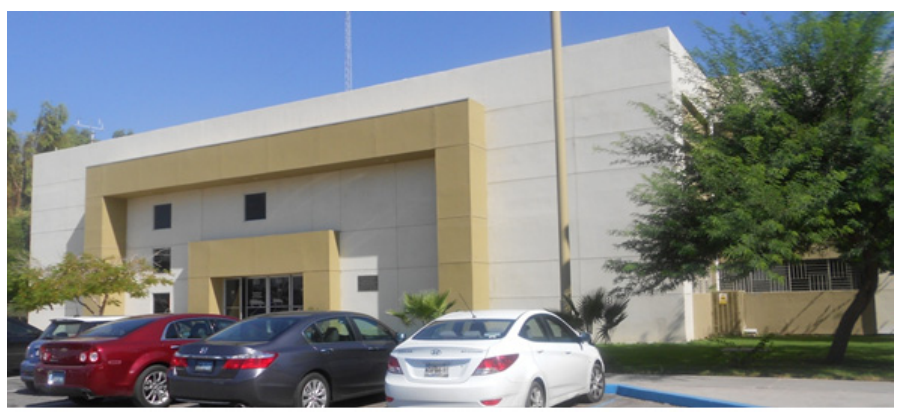

Figure 1: Old two floor building of the IoE.

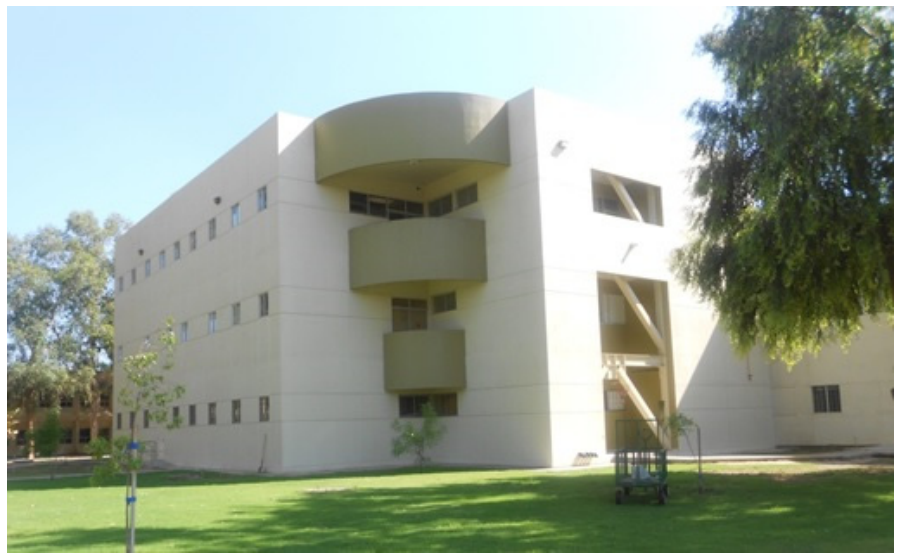

Figure 2: New three floor building of the IoE.

\subsection{Consumption of electric energy}

The "Elite Pro" equipment, developed by Pacific Science and Technology, was used for purposes of obtaining the carbon footprint and the ecological footprint resulting from the consumption of electric energy. Measurements of the consumption of electric energy by the IoE were taken. The Kwh recorded for the week comprising February 18 to 22 of year 2013 were considered for this purpose. Subsequently, the procedure consisted in obtaining the consumption of electric energy throughout four working days. An average of such measurements was thereby computed for purposes of obtaining a daily estimated and a projection thereof pertaining to representative days of the winter season. Similar measurements were carried out during the month of July to account for the summer season (in Mexicali there are actually only two seasons during the year as a result of extreme weather conditions: summer and winter) [2]. 


\subsection{Water consumption}

The IoE has four water meters. Although there are green areas in the periphery, water used for irrigation purposes was not considered, since it is drawn from a different water distribution system. A water consumption reading was taken on a daily basis at each water meter, and always at the same time: 9:00 am. Monthly water consumptions were used to create a data base, eventually resulting in the computation of an annual value for 2013 .

\subsection{Paper consumption}

For purposes of keeping record on the amount of new paper purchased by the Institute, records of purchase orders kept by the administrative offices were taken into account. Such an amount of paper was converted into kgs. Recycled paper was also considered. The number of kilograms of recycled paper was subtracted from the number of kgs of new paper purchased by the administration offices. The resulting number was converted into $\mathrm{kgs}$ of $\mathrm{CO}_{2}$, thereby allowing for the computation of the carbon footprint, and subsequently of the ecological footprint.

\subsection{IoE members commuting}

A survey was resorted to as an information gathering tool for purposes of quantifying the $\mathrm{CO}_{2}$ generated from transporting personnel and students of the IoE. With such survey, data deemed necessary for purposes of determining the distance of individual addresses to the IoE and to calculate the resulting fuel consumption was obtained.

It is important to emphasize that, unlike others, the ecological footprint of the IoE has taken into account the commuting factor resulting from air travel undertaken by the faculty and graduate students, thereby highlighting the large amount of emissions stemming from such activities, thus affording an area of opportunity aimed at reducing the ecological footprint of the IoE.

\subsection{Construction of the IoE building}

The present paper took into account the methodology developed and utilized in 1998 by the School of Architecture of Vallés in Spain [3], known as Research Model for Sustainable Buildings (MIES for its acronym in Spanish), which quantifies the amount of energy invested in the making of building material used for construction purposes, and converts it to $\mathrm{kgs}$ of $\mathrm{CO}_{2}$. Since the MIES study conducted at Spain, conversions from $\mathrm{Kw} / \mathrm{h}$ to $\mathrm{kgs}$ of $\mathrm{CO}_{2}$ were carried out with information from that country. In the present study the data on the density of materials used, as well as the amount of energy it took to produce them were based on information provided by the Comisión Federal de Electricidad (hereinafter, the "CFE" for its acronym in Spanish), the Mexican power utility, for purposes of converting such data to $\mathrm{CO}_{2}$. 
The data base of the materials that were used was obtained from the budget file, which was provided by the UABC Planning Office in charge of the project for the new three floor building of the IoE that was built back in 2010. The final data are given in $\mathrm{kgs}$ of $\mathrm{CO}_{2} / \mathrm{m}^{2}$ of construction. This factor will be used for purposes of assessing the old two floor IoE building as the information on the materials that were used to construct the edifice in 1997, the list of materials or the budget file were not available.

\section{Ecological footprint}

Once the carbon footprint emitted to the atmosphere from each one of the previously mentioned factors was obtained, it was subsequently converted into ecologically productive lands.

The forest area required for purposes of absorbing the $\mathrm{CO}_{2}$ generated by the aforementioned consumption of resources and generation of residuals is calculated. Upon dividing the amount of $\mathrm{CO}_{2}$ emitted to the atmosphere by the fixing capacity of the forest mass the forest area required is obtained, since Mexicali is not located along a coastal zone. The area occupied by the building will be directly added to the aforesaid amount of forest. The fixation rate of 6.27 ton $\mathrm{CO}_{2} /$ ha/year as used by the University of Compostela in Spain will be applied at this stage [4].

Therefore the ecological footprint is calculated as per the following formula:

$$
\begin{aligned}
\text { Ecological footprint }= & \text { Carbon footprint }+ \text { Area of the IoE } \\
& \text { fixing capacity }
\end{aligned}
$$

However, to be able to compare the ecological footprint of the IoE with that of other institutions, global hectares (hg), defined herein as a hectare with an average world capacity to produce resources and absorb residuals need to be used. The equivalent factors (Table 1) [5] translate a specific type of terrain (forests, seas...) to the universal unit for the productive area, which is the global hectare (hag).

Table 1: Equivalent factors.

\begin{tabular}{|l|c|}
\hline \multicolumn{1}{|c|}{ Area type } & Equivalent factor (hag/ha) \\
\hline Agriculture (main lands) & 2.21 \\
\hline Agriculture (marginal lands) & 1.79 \\
\hline Forests & 1.34 \\
\hline Cattle brand & 0.49 \\
\hline Fishery (sea waters) & 0.36 \\
\hline Fishery (continental waters) & 0.36 \\
\hline Artificialized & 2.21 \\
\hline
\end{tabular}

In the present study, forest factor 1.34 was used to convert the ha to hag, as the emissions are absorbed by this type of surface area. 


\section{Results analysis}

\subsection{Transportation}

Transportation of all members of the IoE for purposes of commuting back and forth from their homes to their workplace has been studied by resorting to surveys. A stratified sampling between the various components by considering the occupation of each individual that was surveyed (students, faculty members, service and managerial personnel) was carried out. Such survey offers information on sundry variables or factors that influence the calculation of the ecological footprint.

The most relevant results of the survey were as follows:

- The most resorted to transportation service was the automobile (89\%).

- More than $67 \%$ of the population that makes use of the automobile drives a four-cylinder one vehicle.

- $\quad 59 \%$ of the population drives vehicles with year models from 1999 to 2005 .

- Only one single person drives a diesel motor vehicle.

Emissions to the atmosphere were obtained by considering the distances travelled and the transportation used, which are presented as follows:

Table 2: $\mathrm{Kgs}$ of $\mathrm{CO}_{2} /$ year for transportation at the IoE.

\begin{tabular}{|l|c|c|r|r|r|}
\hline \multicolumn{7}{|c|}{ Kgs of CO2/year } \\
\hline Status & Quantity & $\begin{array}{c}\text { Transport } \\
\text { in the city }\end{array}$ & Airplane trips & $\begin{array}{c}\text { Transport in } \\
\text { the city/capita }\end{array}$ & $\begin{array}{c}\text { Air travels/ } \\
\text { capita }\end{array}$ \\
\hline Students & 102 & $41,226.5$ & $187,712.7$ & 404.18 & $1,840.32$ \\
\hline Faculty & 34 & $12,526.84$ & $114,692.9$ & 368.44 & $3,373.32$ \\
\hline Administrative & 10 & $5,739.4$ & 6,750 & 573.94 & 675.00 \\
\hline Other & 3 & $1,136.2$ & 0 & 378.73 & 0.00 \\
\hline & 149 & $60,628.94$ & $309,155.6$ & & \\
\hline
\end{tabular}

As can be observed, the administrative group is the largest emitter of $\mathrm{CO}_{2}$ to the atmosphere resulting from its transportation throughout the city, with $573.94 \mathrm{kgs}$ of $\mathrm{CO}_{2} /$ capita as a yearly average. With regard to air traveling, the faculty members accounted for the highest emissions with $3373.32 \mathrm{kgs}$ of $\mathrm{CO}_{2}$ /capita as a yearly average. And lastly, the most important number is the amount of $\mathrm{kgs}$ of $\mathrm{CO}_{2}$ associated to all the members of the $\mathrm{IoE}$, which reaches $369,789.54 \mathrm{kgs}$ of $\mathrm{CO}_{2} /$ year.

\subsection{Electric energy consumption}

In 2013, two measuring tasks were undertaken for purposes of obtaining the daily averages of consumption during the summer and winter seasons. 
Daily consumption average for the winter season: $888.51 \mathrm{Kwh}$

Daily consumption average for the summer season: $3345.57 \mathrm{Kwh}$

By taking into account the significant difference in the average daily consumption from season to season, due mainly to the amount of energy that is consumed by the $\mathrm{A} / \mathrm{C}$ systems, the months during which the $\mathrm{A} / \mathrm{C}$ units of the $\mathrm{IoE}$ were working were considered for purposes of estimating the annual consumption average, to wit: April, June, July, August, September during the summer season, and the remaining months, that is, October, November, December, January, February and March, as the winter season.

According to the CFE, for each Gwh that is generated in Mexico, 440 tons of $\mathrm{CO}_{2}$ are emitted onto the atmosphere. Thus, $240,940.82 \mathrm{kgs}$ of $\mathrm{CO}_{2}$ were emitted due to electricity consumption on the part of the IoE during 2013, which entails $1616.94 \mathrm{~kg}$ of $\mathrm{CO}_{2} /$ capita.

\subsection{Water use}

Water consumption has been monitored by taking daily readings on the four meters located at the IoE. During year 2013, $2280 \mathrm{~m}^{3}$ of water were consumed.

The amount of $\mathrm{CO}_{2}$ obtained was as follows:

$$
\text { Ton } \left.\mathrm{CO}_{2}=\left(\mathrm{m}^{3} \text { of water } * 0.449 \mathrm{Kwh} / \mathrm{m}^{3}\right) / 1000000 * 440 \mathrm{Kwh} / \text { ton } \mathrm{CO}_{2}\right)
$$

where:

$-\mathrm{m}^{3}$ of water $=$ annual consumption of water in $\mathrm{m}^{3}$

- $0.449 \mathrm{Kwh} / \mathrm{m}^{3}=$ energy required to draw potable water from wells and the Colorado River in Mexicali

- $440 \mathrm{Kw} /$ ton $\mathrm{CO}_{2}=$ tons of $\mathrm{CO}_{2}$ produced from $\mathrm{Gwh}$ of energy that was consumed

- $1,000,000=$ Gwh to Kwh conversion factor

- The $\mathrm{CO}_{2}$ that was emitted amounted to 0.4504368 tons, or $450.437 \mathrm{kgs}$, or $3.02 \mathrm{~kg}$ of $\mathrm{CO}_{2} /$ capita generated to supply energy for water consumption purposes at the IoE.

\subsection{Paper consumption}

In 2013, 562.42 $\mathrm{kg}$ of virgin paper were purchased, and during that same period $348 \mathrm{~kg}$ of recycled paper were collected. According to Arroyo et al. 2006 [7], the emission factor for virgin paper is 1.87 ton $\mathrm{CO}_{2} /$ ton of paper and for recycled paper is 0.61 ton $\mathrm{CO}_{2} /$ ton of paper.

It may be stated that due to paper usage, 1.051 equivalent tons of $\mathrm{CO}_{2}$ based on the virgin paper that was purchased were emitted, and that the $348 \mathrm{~kg}$ of recycled paper that were collected avoided the emission of 0.21228 tons, i.e. $212.28 \mathrm{~kg}$ of $\mathrm{CO}_{2}$, which yielded $839.44 \mathrm{kgs}$ of $\mathrm{CO}_{2}$ as a result for this item, or $5.63 \mathrm{kgs}$ of $\mathrm{CO}_{2} /$ capita.

\section{Construction of the IoE buildings}

In order to know the emissions derived from the construction of the two buildings of the IoE, the weight of the materials used in their construction and utilized the 
data from the MIES project from Spain was taken into account, previously mentioned, to get the $\mathrm{MJ} / \mathrm{Kg}$ rate to obtain the energy that was needed to manufacture each material utilized in their construction. For the final calculation data from $\mathrm{CFE}$ was utilized to quantify the amount of emissions to the atmosphere derived from the use of energy to determine the emissions of $\mathrm{CO}_{2}$ for each construction material under Mexican standards. This was done to translate the results to be applied in Mexico, as the MIES project had a similar factor but for the sources of electric energy in Spain.

In Table 3 the materials used and their emissions to the atmosphere of the newest building (3 floor) are shown.

Table 3: Construction materials utilized at the IoE.

\begin{tabular}{|c|c|c|c|c|c|}
\hline Material & $\begin{array}{c}\text { Weight } \\
\text { (Kg) }\end{array}$ & $\begin{array}{l}\text { Factor } \\
(\mathrm{MJ} / \mathrm{Kg})\end{array}$ & $\begin{array}{c}\text { Energy } \\
\text { (MJ) }\end{array}$ & $\begin{array}{l}\text { Energy } \\
\text { (Kwh) }\end{array}$ & 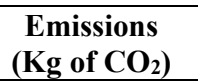 \\
\hline Gypsum & 22054.60 & 7 & 154382.20 & 42883.94 & 18868.93 \\
\hline $\begin{array}{l}\text { Cement and } \\
\text { cemenquin }\end{array}$ & 13045.17 & 7 & 91316.19 & 25365.61 & 11160.86 \\
\hline Wood & 3423.34 & 3 & 10270.02 & 2852.78 & 1255.22 \\
\hline Glass & 1602.63 & 19 & 30450.12 & 8458.37 & 3721.68 \\
\hline Steel & 161370.05 & 43 & 6938912.15 & 1927475.60 & 848089.26 \\
\hline Aluminium & 10393.54 & 210 & 2182645.31 & 606290.36 & 266767.76 \\
\hline \begin{tabular}{|l|} 
Concrete \\
block
\end{tabular} & 23165.25 & 1.03 & 237070.21 & 65852.84 & 28975.24 \\
\hline \begin{tabular}{|l|} 
Copper \\
\end{tabular} & 121.57 & 90 & 10941.84 & $3,039.40$ & 1337.33 \\
\hline $\begin{array}{l}\begin{array}{l}\text { Reinforced } \\
\text { concrete }\end{array} \\
\end{array}$ & 1775898.48 & 1.7 & 3019027.42 & 838618.73 & 368992.24 \\
\hline Mortar M40 & 105218.40 & 1 & 105218.40 & 29227.33 & 12860.02 \\
\hline \begin{tabular}{|l|} 
Synthetic \\
painting
\end{tabular} & 939.86 & 100 & 93986.99 & 26107.49 & 11487.29 \\
\hline \begin{tabular}{|l} 
Expanded \\
polystyrene
\end{tabular} & 6724.78 & 120 & 806973.84 & 224159.39 & 98630.13 \\
\hline Plastic & 925.49 & 70 & 64784.31 & 17995.64 & 7918.08 \\
\hline Total & 2331883.20 & & 13443363.8 & 3734267.72 & 1643077.8 \\
\hline
\end{tabular}

The total emissions to the atmosphere were divided by 30 years of average useful life equal to $54,769.26 \mathrm{~kg}$ of $\mathrm{CO}_{2}$ corresponding to 2013 since the calculation of ecological footprint is for one year. This amount represents the new 3 floor building only, and a calculation was made to know the emissions $/ \mathrm{m}^{2}$ of construction to the atmosphere using the following relationship:

$$
54769.26 \mathrm{Kg} \text { of } \mathrm{CO}_{2} / 1796.76 \mathrm{~m}^{2}=30.5 \mathrm{Kg} \mathrm{CO}_{2} / \mathrm{m}^{2}
$$

where $1796.76 \mathrm{~m}^{2}$ is the area of the new three floor building.

The total area of the two buildings of the IoE is:

$$
1302.35 \mathrm{~m}^{2} \text { (2 floor) }+1796.76 \mathrm{~m}^{2} \text { (three floor) }=3099.1 \mathrm{~m}^{2}
$$

Therefore, the total amount of $\mathrm{CO}_{2}$ generated was:

$$
\left(30.5 \mathrm{Kg} \mathrm{Co} 2 / \mathrm{m}^{2}\right) \times\left(3099.11 \mathrm{~m}^{2}\right)=94522.9 \mathrm{Kg} / \mathrm{m}^{2}
$$




\section{Ecological global footprint of the IoE}

According to studies on the ecological footprint conducted at the University of Santiago Compostela in Spain [4] it takes a hectare of forest to absorb 6.27 tons of $\mathrm{CO}_{2}$ /year. That granted, and upon applying a conversion factor to convert from hectares (h) to global hectares (hg), equal to 1.34, and when applied to the results thus obtained, both carbon and ecological footprints are shown in Table 4.

Table 4: Carbon print and ecological footprint factors for the IoE.

\begin{tabular}{|l|c|c|c|}
\hline Factor & $\begin{array}{c}\text { Carbon footprint (kg } \\
\text { of } \mathbf{C O}_{2}\end{array}$ & $\begin{array}{c}\text { Ecological } \\
\text { footprint } \\
\text { (ha) }\end{array}$ & $\begin{array}{c}\text { Ecological } \\
\text { global } \\
\text { footprint } \\
\text { (hag) }\end{array}$ \\
\hline Transportation & $369,784.54$ & 58.98 & 74.31 \\
\hline Electric energy & $240,924.82$ & 38.43 & 48.42 \\
\hline Water & 450.44 & 0.07 & 0.09 \\
\hline Paper & 839.44 & 0.13 & 0.17 \\
\hline Construction & $94,522.90$ & 15.07 & 19.89 \\
\hline Total & $\mathbf{7 0 6 , 5 2 2 . 1 0}$ & $\mathbf{1 1 2 . 6 1}$ & $\mathbf{1 4 2 . 8 7}$ \\
\hline
\end{tabular}

In the perception of a common stakeholder who is acquainted with areas measurement, the results of the EF in hectares or $\mathrm{m}^{2}$ is quite easy to relate it with known spaces; for instance, the EF of the IoE amounts to $149 \mathrm{hg}$, and is equivalent to seven times the area covered by the UABC main campus [7] in Mexicali, Baja California.

When considering the population of the IoE, made up of 149 individuals (102 students, 34 faculty, 10 administrative and 3 cleaning and maintenance personnel), its ecological footprint is $0.75 \mathrm{ha} /$ capita and $0.95 \mathrm{hag} /$ capita.

\subsection{Ecological footprint of the IoE vs. other academic institutions}

Studies of this type have been conducted at other universities around the world [6, $8-11]$. Table 5 shows a variety of outcomes depending on various factors that are taken into consideration: electric energy, transportation, food, solid residuals, water, construction, recycled paper and population. Once the results are analyzed, interesting interpretations may be drawn in the case of the IoE: the high value of the EF (1.0 hag/capita), when compared to that of other institutions considering the small population that is accounted for, may be based on the calculation of emissions resulting from air traveling and commuting in the city. 
Table 5: Ecological footprint of several academic institutions in the world.

\begin{tabular}{|c|c|c|c|c|c|}
\hline $\begin{array}{l}\text { Academic } \\
\text { Institutions }\end{array}$ & Location & Year & Factors & Population & $\begin{array}{c}\text { EF } \\
\text { hag/cap }\end{array}$ \\
\hline $\begin{array}{l}\text { University of } \\
\text { Toronto, } \\
\text { Mississauga }\end{array}$ & $\begin{array}{l}\text { Ontario, } \\
\text { Canada }\end{array}$ & 2005 & $\begin{array}{l}\text { Energy, food, } \\
\text { transportation, } \\
\text { residuals, water, } \\
\text { construction } \\
\end{array}$ & 12,121 & 1.04 \\
\hline $\begin{array}{l}\text { University of } \\
\text { Newcastle }\end{array}$ & $\begin{array}{l}\text { Newcastle, } \\
\text { Australia }\end{array}$ & 1999 & $\begin{array}{l}\text { Energy, food, } \\
\text { transportation, } \\
\text { construction }\end{array}$ & 11,830 & 0.19 \\
\hline $\begin{array}{l}\text { University } \\
\text { of Holme, } \\
\text { Lacy College }\end{array}$ & $\begin{array}{l}\text { Herefordshire, } \\
\text { England }\end{array}$ & 2001 & $\begin{array}{l}\text { Energy, food, } \\
\text { transportation, } \\
\text { residuals, water }\end{array}$ & 6,000 & 0.56 \\
\hline Colorado College & Colorado, USA & 2001 & $\begin{array}{l}\text { Energy, food, } \\
\text { transportation, } \\
\text { residuals, water, } \\
\text { construction } \\
\end{array}$ & 2,008 & 2.24 \\
\hline $\begin{array}{l}\text { University of } \\
\text { Redlands }\end{array}$ & $\begin{array}{l}\text { California, } \\
\text { USA }\end{array}$ & 1998 & $\begin{array}{l}\text { Energy, } \\
\text { transportation, } \\
\text { residuals, water }\end{array}$ & 2,727 & 0.85 \\
\hline $\begin{array}{l}\text { Universidad de } \\
\text { Santiago }\end{array}$ & $\begin{array}{l}\text { Santiago de } \\
\text { Compostela, } \\
\text { Spain }\end{array}$ & 2008 & $\begin{array}{l}\text { Energy, } \\
\text { transportation, } \\
\text { paper, water, } \\
\text { construction }\end{array}$ & 32,246 & 0.16 \\
\hline $\begin{array}{l}\text { Universidad de } \\
\text { León, Campus de } \\
\text { Vegazana }\end{array}$ & León, Spain & 2006 & $\begin{array}{l}\text { Energy, } \\
\text { transportation, } \\
\text { paper, water, } \\
\text { construction } \\
\end{array}$ & 14,000 & 0.45 \\
\hline $\begin{array}{l}\text { Instituto de } \\
\text { Ingeniería, } \\
\text { Campus Mexicali, } \\
\text { UABC }\end{array}$ & $\begin{array}{l}\text { Mexicali, BC, } \\
\text { México }\end{array}$ & 2006 & $\begin{array}{l}\text { Energy, } \\
\text { transportation, } \\
\text { water, paper, } \\
\text { construction }\end{array}$ & 149 & 0.95 \\
\hline
\end{tabular}

\section{Conclusions}

The present work recommends resorting to the use of the ecological footprint as a tool to measure sustainability as part of a permanent program within the IoE, conducive to helping to have arguments for decision making when seeking to accomplish a reduction in the consumption of energy, water, paper, to optimize the use of construction materials and transportation, as well as to lower the emissions of $\mathrm{CO}_{2}$ onto the atmosphere in general. By including studies on the carbon footprint and the ecological footprint at universities that pursue sustainability as an objective, such institutions will be better equipped at aiming to achieve a social-economic-environmental balance. The ecological footprint analysis should be considered as a recurrent exercise to enter into an improvement cycle. 


\section{References}

[1] Wackernagel, M. \& Rees, W. Our ecological footprint. Reducing human impact on earth, New Society Publisher, Canada, pp. 51-57, 1996.

[2] Garcia, C.O.R., Jauregui, O.E., Toudert, D. and Tejeda, M.A. Detection of the urban heat island in Mexicali, B.C., Mexico and its relationship with land use. Atmósfera, 20, pp. 111-131, 2007.

[3] i burgos, A.C. and López, I. Informe MIES: Una aproximación al impacto ambiental de la Escuela de Arquitectura del Vallés: bases para una política. Universitat Politécnica de Catalunya, 2005.

[4] López, R., Taboada J.L., López, N. Impacto Ambiental en Centros da USC Vicerrectoría de Calidad de Planificacion, Universidad de Santiago de Compostela. Dirección Xeneral de Desenvolvemento Sostible. Xunta de Galicia, 2008.

[5] WWF, Global Footprint Network, Informe Planeta Vivo 2006. http://www.footprintnetwork.org/images/uploads/LPR2006_Spanish.pdf

[6] Cuamea, V.F. Plan de desarrollo institucional de la Universidad Autónoma de Baja California 2011-2014, 2011.

[7] Arroyo, P. Alvarez, J.M., Falagán, J., Martínez, C. Ansola, G. de Luis E. Huella ecológica del campus de Vegazana, Instituto de Medio Ambiente, Universidad de León. Área de Ecología. Facultad de Ciencias Biológicas y Ambientales. Campus de Vegazana, España, 2006.

[8] Busquets, P, Sanchez, J. La Huella ecológica de la EUPM, www.upc.es/mediambient, 2000.

[9] Cárdenas C., Peinado A, Mora A., Moreno, L., Huella ecológica de la UGR, Universidad de Granada, Vicerrectorado de Calidad Ambiental, Bienestar y Deporte, 2010.

[10] Tomaselli, M., Investigación de la huella ecológica en la Universidad San Francisco, 2004.

[11] Venetoulis, J. Assessing the ecological impact of a university: the ecological footprint for the University of Redlands. International Journal of Sustainability in Higher Education, 2(2), pp. 180-197, 2001. 